\title{
Evaluation of catchment contributing areas and storm runoff in flat terrain subject to urbanisation
}

\author{
O. V. Barron, D. Pollock, and W. Dawes \\ CSIRO Land and Water, Perth, Western Australia
}

Received: 21 September 2009 - Published in Hydrol. Earth Syst. Sci. Discuss.: 30 October 2009

Revised: 7 October 2010 - Accepted: 24 January 2011 - Published: 11 February 2011

\begin{abstract}
Contributing Catchment Area Analysis (CCAA) is a spatial analysis technique developed and used for estimation of the hydrological connectivity of relatively flat catchments. It allows accounting for the effect of relief depressions on the catchment rainfall-runoff relationship which is not commonly considered in hydrological modelling. Analysis of distributed runoff was based on USDA runoff curves numbers (USDA, 1986), which utilised the spatial information on land cover and soil types, while CCAA was further developed to define catchment area contributing to river discharge under individual rainfall events. The method was applied to the Southern River catchment, Western Australia, showing that contributing catchment area varied from less than $20 \%$ to more than $60 \%$ of total catchment area under different rainfall and soil moisture conditions. Such variability was attributed to a compensating effect of relief depressions. CCAA was further applied to analyse the impact of urbanisation on the catchment rainfall-runoff relationship. It was demonstrated that in addition to an increase in runoff coefficient, urbanisation leads to expansion in the catchment area contributing to the river flow. This effect was more evident for the most frequent rainfall events, when an increase in contributing area was responsible for a $30-100 \%$ rise in predicted catchment runoff.
\end{abstract}

\section{Introduction}

Prediction of the rainfall-runoff relationship in flat catchments and particularly under land use alteration is challenging. In semi-arid and arid regions runoff estimation is commonly based on Hortonian Infiltration Excess (HIA) approach (Bryan and Yair, 1982) and on a single direction

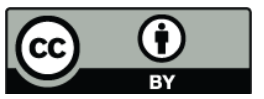

Correspondence to: O. V. Barron (olga.barron@csiro.au) algorithm using pit-free DEM (Beven, 1979). However in flat catchments, where landforms are formed by aeolian processes resulting in a series of surface depressions and a dunelike landscape, application of such approaches are limited due to limited hydrological catchment connectivity.

Hydrological connectivity concepts are an emerging approach for the analysis of runoff generation (Bracken and Croke, 2007). It allows accounting for landscape connectivity and/or hydrological connectivity, defining various aspects of the water transport from one part of the catchment to another and overall contributing to catchment runoff. The concept of a "catchment contributing area" used in this study is closely linked with a term "hydrologic connectivity" as suggested by James and Roulet (2007). They defined it as hydrologically relevant spatial patterns of properties (e.g. permeability or soil or land cover) or state variables (moisture content of soil) that facilitate flow and transport in a hydrologic system. A similar interpretation was adopted by Western et al. (2001). This definition is broadly in agreement with that by Bracken and Croke (2007) used in their conceptual framework describing relevant "landscape position" and "delivery pathways".

Bracken and Croke (2007) also indicated the differences between static and dynamic aspect of catchment hydrological connectivity and associated runoff generation. The former is closely related to definition of the hydrological runoff (response) unit (HRU) (Bull et al., 2003) or hydrologically similar surfaces (HYSS) (Kirkby et al., 2002). These describe the certain areas within a catchment which due to soil type, slopes, land use and overall geomorphologic setting show a similar rainfall/runoff relationship. However depending on their position in the landscape and proximity to the river they may or may not contribute to overall catchment runoff.

The changes in the land or water use within the catchment were classified (Bracken and Croke, 2007) as a dynamic aspect of catchment connectivity. This could be related to dams' installation (Callow and Smettem, 2009; Hu et al.,

Published by Copernicus Publications on behalf of the European Geosciences Union. 
2008) or drains use for agricultural purposes (Payraudeau et al., 2009) which can reduce or increase the catchment hydrologic connectivity. One of such changes, urbanisation, has a particularly profound effect on a catchment water balance and hydrological regime. Increasing impervious surfaces alters the pathway by which rainwater is transferred to surface water networks and groundwater systems. It is broadly accepted that due to the impact of impervious surfaces, urbanisation leads to an increase in runoff from individual storm events and annual runoff (Grove et al., 2001; Jennings and Jarnagian, 2001). It has also been reported that urbanisation increases the magnitude of peak runoff and the rate of hydrograph rise and recession, but reduces the lag time between rainfall and runoff response (Burns et al., 2005; Rose and Peters, 2001).

The magnitude of this impact is dependent on the proportion of urban development to the total catchment area, but also on the intensity of rainfall events. The greatest effect on stormwater yields is found in medium and low intensity rainfall events rather than in extreme rainfall conditions (Niehoff et al., 2002; Camorani et al., 2005).

The effects of urbanisation on catchment runoff are particularly significant in areas affected by inundation, which may occur in flat terrain and may be associated with a shallow groundwater table. In such cases large volumes of water, previously stored in the landscape and lost to evaporation, are required to be drained. Under such conditions, variations in rainfall-runoff relationship are not only affected by impervious surfaces, but also by an increase in catchment area contributing to the river flow.

The study presented here is part of a larger project which aims to develop a decision support tool to facilitate catchment urbanisation within water sensitive environments. The overall focus of the project is to quantify the impacts associated with urban development on surface water, groundwater and wetlands water balance. This paper examines the effect of catchment connectivity on total volumetric runoff associated with single rainfall events. Peak flow, flooding and other details of discharge hydrographs fall outside the scope of the reported analysis.

\section{Case-study}

Perth, the capital city of Western Australia, is experiencing fast growth with urbanisation of greenfield sites facing substantial environmental constrains. This is the case in one of the fastest developing regions, the Southern River catchment $\left(155 \mathrm{~km}^{2}\right)$ (Fig. 1), where urban expansion is challenged by shallow groundwater tables, high nutrient concentrations in surface and groundwater, seasonal inundation, presence of conservation wetlands, and proximity to the Swan-Canning Estuary. Such complex environmental settings necessitate great care when altering catchment land and water management.

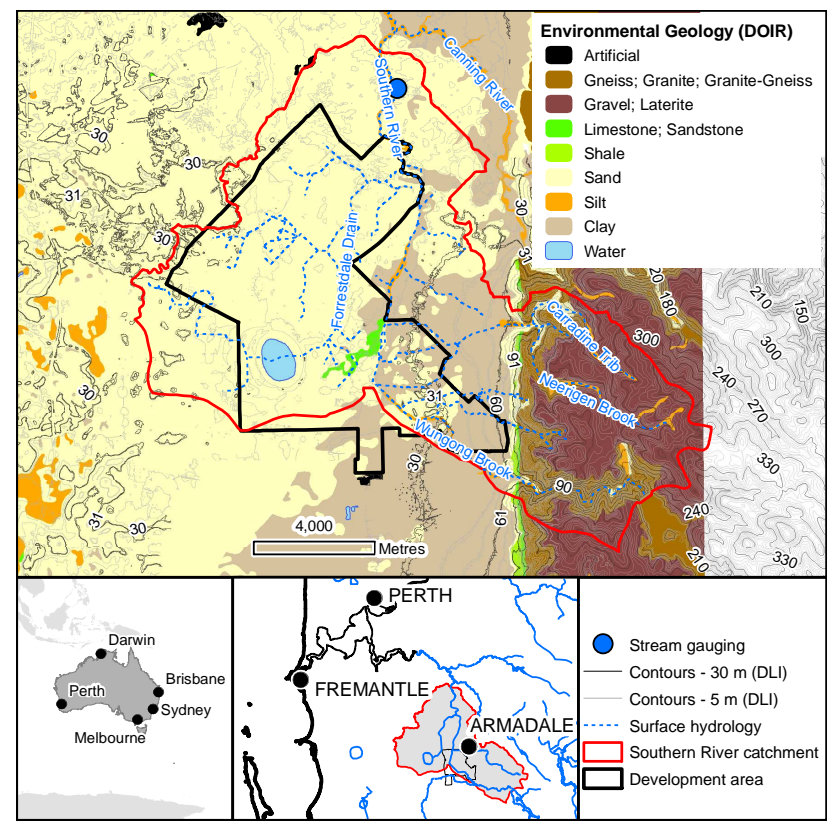

Fig. 1. Location, topography and geology map.

The elevated upland area in the south-east of this catchment includes the upper reaches of the river. The rest of the catchment is mainly a flat low-lying area underlined by 20 $60 \mathrm{~m}$ of Quaternary fluvial and aeolian deposits; Bassendean Sand in the west, and the Guildford Formation, predominantly clays, in the east of the catchment adjacent to the Darling Scarp. Low surface gradient and limited drainage capacity cause seasonal inundation and the establishment of wetlands.

There are two major land uses in the low-lying part of the catchment: urban and rural. The currently urbanised areas include suburban housing and infrastructure on the northern and eastern boundaries of the catchment, covering less than $30 \mathrm{~km}^{2}$. The remaining rural part includes the state forest area in the hills, remnant vegetation and cleared land used for hobby horticultural and livestock farming as illustrated in Fig. 2.

The average annual precipitation in the region is $891 \mathrm{~mm}$ over the period 1889 to 2006 . More than $80 \%$ of annual rain falls during the winter months, while the summer months are usually dry and warm. This rainfall generates on average $87 \mathrm{~mm}$ of runoff and the average annual river discharge is $13 \mathrm{GL} /$ year (or $0.41 \mathrm{~m}^{3} \mathrm{~s}^{-1}$ ). A monthly water balance indicated that runoff is limited during autumn and early winter with monthly volumetric runoff coefficient is less than $2 \%$. It is believed that during this period the substantial storage capacity of the deep sandy soils and wetlands allows the accumulation of rain water with little stormwater yields. In the analysis presented in the following section, this period will be referred to as the "storage recovery stage". 


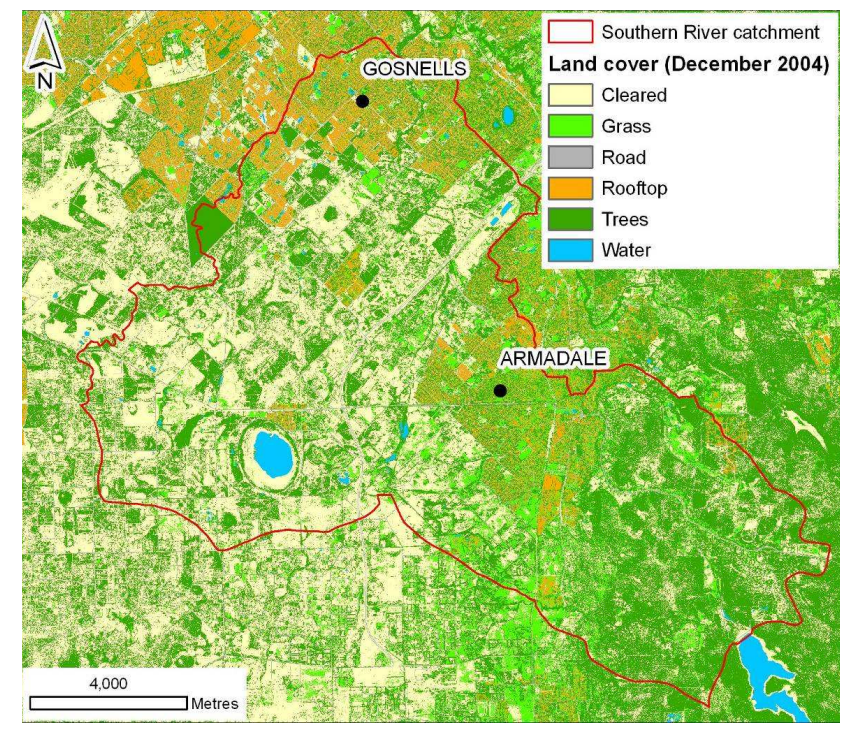

Fig. 2. Land cover map; meteorological stations at Gosnells and Armadale are marked.

The Southern River flow increases significantly during late winter and early spring when monthly volumetric runoff coefficient is greater than $25 \%$. The analysis of the river discharge data for 1997-2006 shows that the increase in the flow rate occurs when the cumulative winter rainfall reaches approximately $400 \mathrm{~mm}$. At this stage the catchment storage is largely filled. This period is referred to as the "storage deficiency stage". During summer, when evaporative losses exceed rainfall, the 'storage depletion stage' occurs.

We suggest that some of the variation in catchment volumetric runoff coefficients during dry and wet periods is attributed to greater catchment area contributing to the river flow during the storage deficiency stage. The effect of the variation in catchment contributing to catchment runoff was investigated using Catchment Contributing Area Analysis (CCAA).

\section{Methodology}

In developing the approach it is assumed that topographically cascading surface depressions in flat and highly permeable landscape can be connected (or linked together) by the transfer of overland flow during individual rainfall events. In the approach a greater contributing catchment area (or "active area" as defined by Ambroise, 2004) under various conditions is adopted as a measure of a greater hydrologic connectivity between landscape and the river. As did James and Roulet (2007), we investigated the change in contributing area as a result of different moisture condition and event rainfall.

CCAA is a GIS-based model, which allows estimation of both the sub-catchment area contributing to river flow in response to an individual rainfall event, and the catchment runoff generated during a single rainfall event. CCAA includes a number of steps, illustrated in Fig. 3.

\subsection{Definition of hydrological response units}

Following HRU or HYSS concepts, the runoff generation within catchment was estimated by defining hydrological response units as a unique combination of soil (clay and sand) and land cover classes. The land cover types were identified using both raster and vector spatial data sets reflecting information for 2004. Maximum likelihood classification of the digital aerial photography created three broad classes: "grass", "trees/water" and "rooftops/roads/cleared". Additional spatial data were further used to separate these classes:

- A map of existing water bodies was used to separate "trees" and "water" classes.

- A road centreline vector data set enabled the assignment of "road" to cells within $4 \mathrm{~m}$ of a centreline.

- Cadastral data were employed to delineate the "rooftops" class in urban areas.

- The cells which were initially classified as "rooftops" or "roads" or "cleared" but fell outside the $4 \mathrm{~m}$ distance from a road centreline and the urban areas, were reclassified as "cleared".

The two soil classes, sand and clay, were delineated based on an environmental geology map (Western Australian Department of Industry and Resources), making the total number of hydrological response units twelve, combining six land use classes ("cleared land", "grass", "road", "rooftop", "trees" and "water") with two soil classes.

\subsection{Estimation of daily volumetric runoff}

The USDA Curve Number (CN) method (USDA, 1986) was employed to estimate runoff from individual storm events for the twelve delineated hydrological response units. Daily rainfall was assumed to be an individual storm event. As a result, $\mathrm{CN}$ varies from 30 representing highly permeable soils with natural woody vegetation cover, to 98 for roads and rooftops.

Under current conditions soil type, vegetation cover, impervious surfaces and superficial storages are constants. However the $\mathrm{CN}$ was varied to account for different soil moisture conditions in summer, with possible infiltration (storage recovery stage), and winter, when groundwater levels rise and infiltration capacity is limited (storage deficiency stage). For simulations of summer conditions, $\mathrm{CN}$ estimation accounts for the soil infiltration rate, presuming that sandy soils infiltrated freely and did not produce much runoff. For winter conditions the $\mathrm{CN}$ was increased to simulate a limit of infiltration due to reduction in available storage. To ensure 


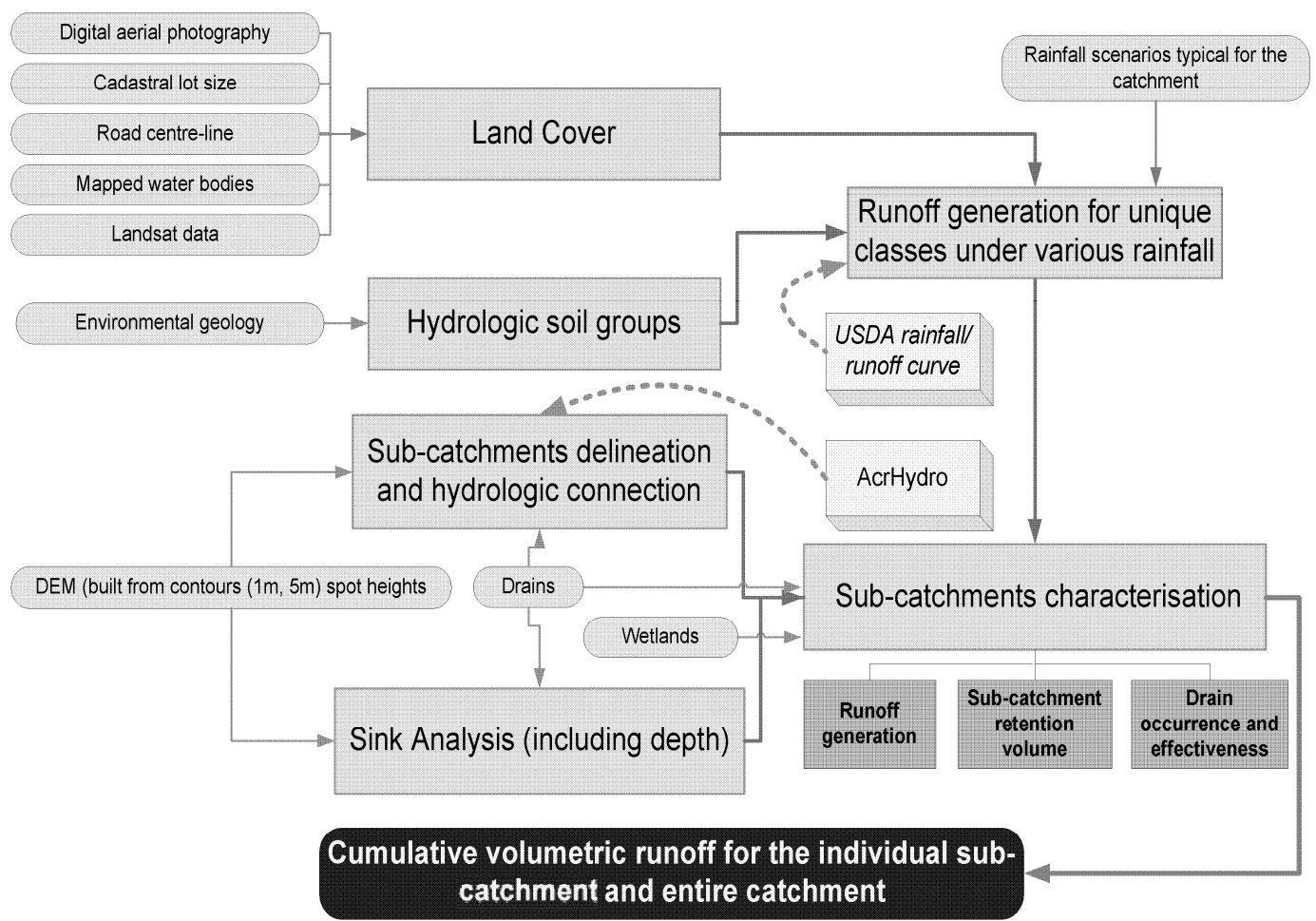

Fig. 3. Framework for Catchment Contributing Area Analysis.

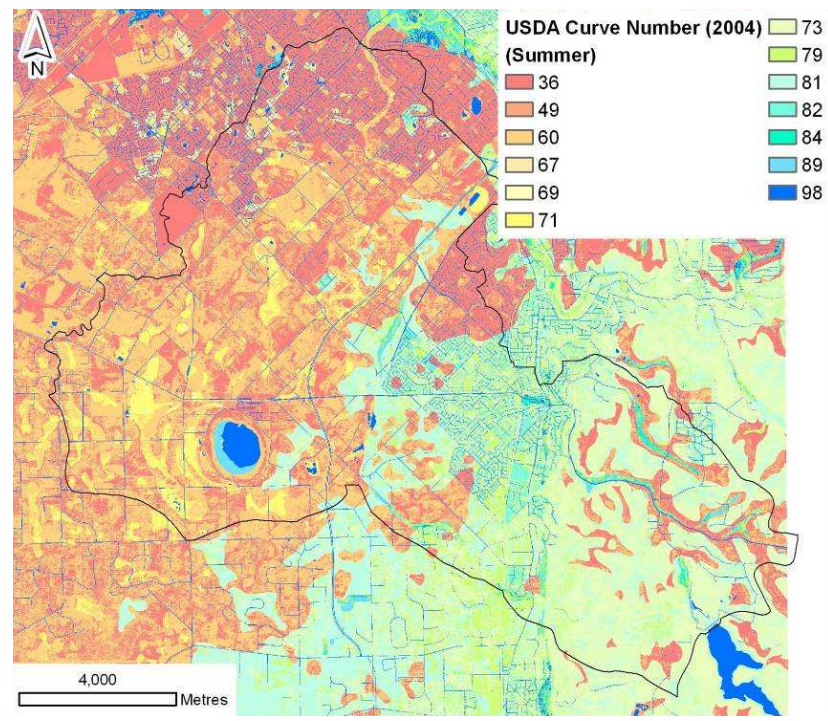

(a)

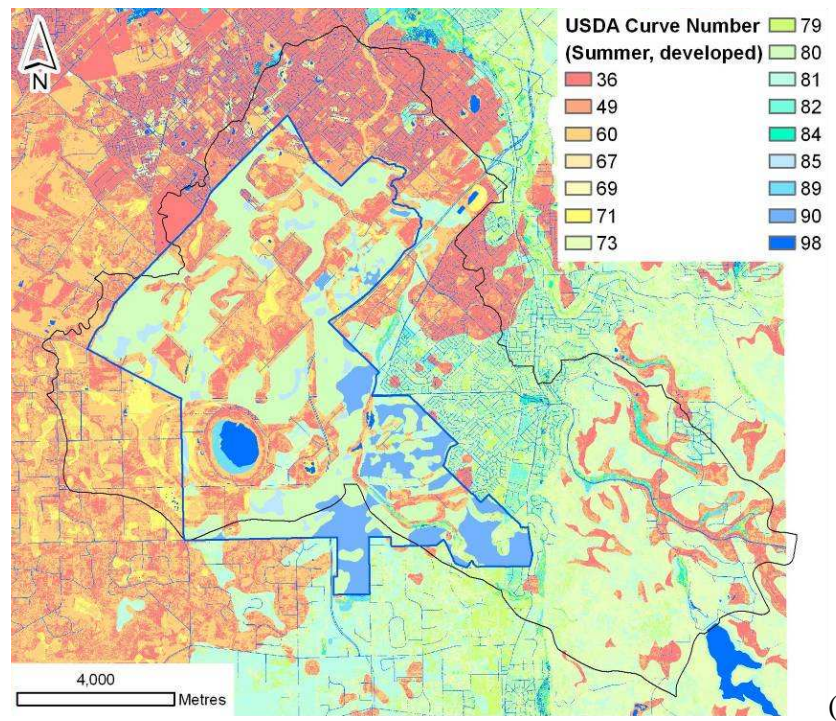

(b)

Fig. 4. USDA Curves applied to the volumetric runoff analysis for (a) predevelopment and (b) post-development conditions.

the consistency of these seasonal variations across the model domain, each $\mathrm{CN}$ was increased to an average between its original value and the maximum $\mathrm{CN}$ of 98 . An example of CN spatial distribution within the catchment during storage recovery stage is illustrated in Fig. 4a.

The developed model of runoff was not fitted by estimating and varying $\mathrm{CN}$ spatially on an event basis to closely match with river records. Instead, the values of $\mathrm{CN}$ are all determined a priori and the model as a whole is validated for current conditions by comparing CCAA results with the total runoff estimated from the river hydrograph.

Simulation of new urban development included the addition of impervious area within the proposed development area and elimination of the predevelopment surface 
depressions. $\mathrm{CN}$ values were selected in accordance with the USDA procedure resulting in an average estimate for each soil type and potential housing density. In this paper, only the case related to medium density development is discussed (Fig. 4b).

\subsection{Estimation of catchment retention capacity and connectivity}

Due to specifics of the catchment landscape there was an expectation that not all runoff generated within HRUs contributes to catchment runoff. The landscape connectivity and potential excess of water within surface depressions were defined within the CCAA model as follows.

DEM analysis indicated that the topography of the catchment presents a mosaic of surface depressions as it is located within a dune type landscape (Fig. 5). Routing the runoff based on cell to cell surface gradient as in Olivera and Maidment (1999) is not directly applicable to such a catchment. Hence the approach described here accounting for cascading surface depressions in a flat landscape, presuming that their contribution to overland flow is only possible when the internal depression storage is filled.

A raster DEM was used to delineate sub-catchments, individual relief depressions and depressions storage capacity $\left(V_{i}\right)$. The raster DEM was built from $1 \mathrm{~m}$ contour data and spot heights of ground surface (1:2000 Digital Topographic data from Western Australia Land Information Services). A hydrology data set, containing known drains and rivers, was used to enforce drainage in the DEM using the Arc Hydro toolset (Maidment, 2002). The DEM was then "filled", allowing catchments and their connectivity to be derived, as shown in Fig. 5.

The relief depressions were attributed with a total storage capacity $\left(V_{i}\right)$, defined as the volume limited by a minimum surface height along the depression perimeter which indicates the level of the water outflow from the depression. An additional attribute defined the presence or absence of a surface water channel.

Within the adopted methodology, the runoff $\left(q_{i}\right)$ generated in an individual relief depression $(i)$ and estimated using $\mathrm{CN}$ values was compared to the depression storage capacity $\left(V_{i}\right)$. When $q_{i}$ exceeds $V_{i}$ the surplus $\left(\Delta_{i}=q_{i}-V_{i}\right)$ was added to channel flow and then to the neighbouring relief depression in accordance with the defined hydrological connectivity between those depressions.

Sequentially the storage capacity $\left(V_{i+1}\right)$ in the receiving depression $(i+1)$ was compared with the sum of two characteristics: the runoff generated within this depression $\left(q_{i+1}\right)$ and the runoff surplus generated in the depression $(i)$ positioned upgradient, $\Delta_{i}$. If $\left(q_{i+1}+\Delta_{i}\right)>V_{i+1}$, the surplus $\left(\Delta_{i+1}\right)$ was further directed to the next hydrologically connected depression.

Only relief depressions which ultimately contribute to the stream network were identified as the catchment contributing

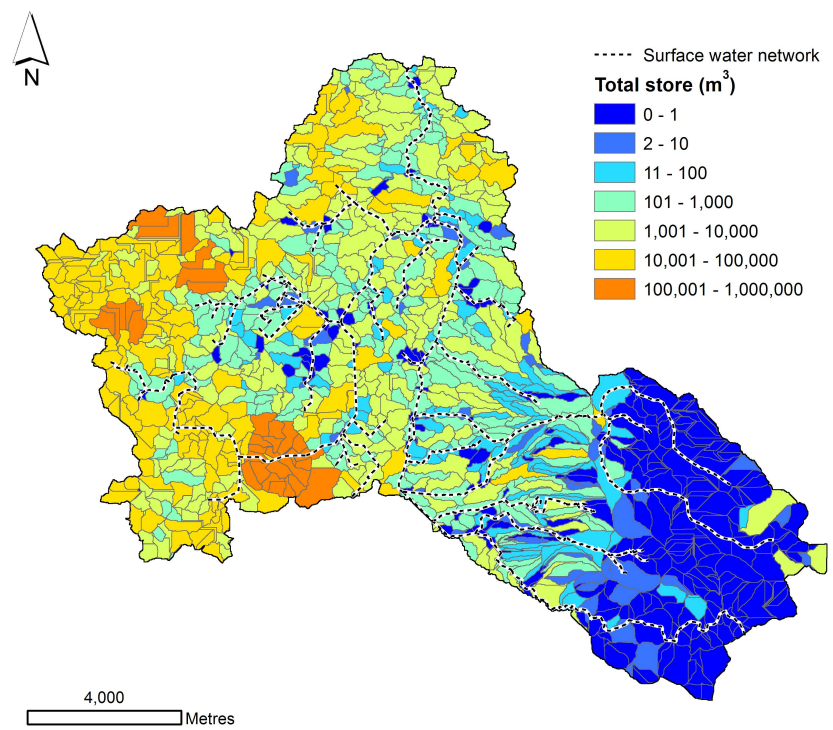

Fig. 5. Stream network and retention volumes in identified surface depressions.

area $\left(A_{\mathrm{cc}}\right)$. This approach allowed estimation of the cumulative volumetric runoff from the sub-catchments $\left(Q_{\mathrm{cc}}\right)$ and at the outflow from the entire catchment. A runoff coefficient associated with the contributing catchment area $\left(\mathrm{RO}_{\mathrm{cc}}\right)$ can be further estimated by $\mathrm{RO}_{\mathrm{cc}}=Q_{\mathrm{cc}} / A_{\mathrm{cc}}$.

Spatial analysis technique was implemented using ArcGIS9.2 (ESRI, 2009a,b) and the Python scripting language (Python Software Foundation, 2009).

A range of rainfall events was selected for analysis, reflecting a $24 \mathrm{~h}$ duration rainfall for specified periods of recurrence typical for the Perth region: $48 \mathrm{~mm}$ (1 year), $62 \mathrm{~mm}$ ( 2 years), $76 \mathrm{~mm}$ (5 years), $85 \mathrm{~mm}$ (10 years), $99 \mathrm{~mm}$ (20 years), $118 \mathrm{~mm}$ (50 years) and $134 \mathrm{~mm}$ (100 years). More common rainfall events $(<48 \mathrm{~mm})$ and other randomly selected events were included to show a representative range of daily rainfall for model simulation. The range also included the highest daily rainfall event of $147 \mathrm{~mm}$ recorded in the area.

The model validation was based on comparison of the simulated volumetric runoff to the measured total river discharge at the outflow from the catchment, generated by a single rainfall event.

\subsection{Results interpretation}

The purpose of this paper is to identity the effect of the changing catchment contribution area $\left(A_{c c}\right)$ on runoff generation in the catchment. The analysis of the model outcome was based on simultaneous estimation of the areas $A_{a}$ and $A_{b}$ contributing to the river flow under two scenarios $a$ and $b$ and associated runoff $Q_{a}$ and $Q_{b}$ generated from those areas. As under a greater rainfall or soil saturation, an increase in the catchment contribution area, $\Delta A=A_{b}-A_{a}$ causes in 


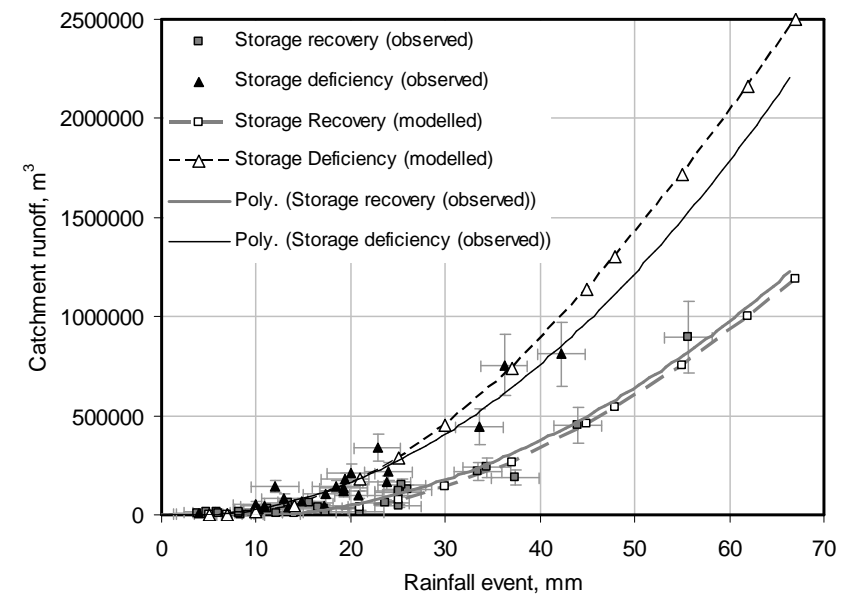

Fig. 6. Catchment volumetric runoff (modelled and observed) during storage recovery and storage deficiency stages; the error bars show the standard deviation between the long-term daily rainfall records at the two local weather stations equal to $5 \mathrm{~mm}$ and the error related to the flow measurements estimated as $\pm 20 \%$.

increase in runoff $\Delta Q=Q_{b}-Q_{a}$. The effect of variation in the catchment contributing area $(\delta)$ between scenarios $a$ and $b$ on the variation in catchment runoff can then be estimated as:

$\delta=\frac{Q_{\Delta A}}{Q_{b}-Q_{a}}(\%)$

where $Q_{\Delta A}$ is the volumetric runoff generated only within the area $\Delta A$.

As described above CCAA allows estimation of both $Q$ and $A$ for any given sub-catchment, rainfall intensity and for a number of scenarios. Accordingly, $Q_{\Delta A}$ and $\Delta Q=Q_{b}-$ $Q_{a}$ were estimated for a number of scenarios discussed in this paper.

\section{Historical data}

Historical rainfall data for the period between 1889 and 2006 were available at two meteorological stations shown in Fig. 2. Simultaneous analysis of these data and the hourly record of the river discharge indicate that rainfall events less than $5 \mathrm{~mm}$ produce low runoff. It also showed that on average there are 54 rainfall events per year greater than or equal to $5 \mathrm{~mm}$ and that over the winter period between May and September on average 10 daily rainfall events greater than $5 \mathrm{~mm}$ may occur during each month (Table 1).

The duration of a flow event in response to an individual daily rainfall varied between $24 \mathrm{~h}$ in the summer and about 7 days in the late winter. In order to estimate a runoff volume associated with single daily rainfall only rainfall events which were followed by at least 7 dry days were used for analysis; 51 such events occurred between 1997 and 2004. Using river discharge data measured in the outflow from the
Table 1. Rainfall statistics for 1889-2006 in Southern River catchment showing number of rain days per year; annual average rainfall in the area is $891 \mathrm{~mm}$, maximum and minimum recorded annual rainfall are $1371 \mathrm{~mm}$ and $499 \mathrm{~mm}$ respectively.

\begin{tabular}{lrlrrrrrr}
\hline \multicolumn{2}{c}{ Number of rain days } & & \multicolumn{5}{c}{ Rainfall Intensity $\left(\mathrm{mm} \mathrm{day}^{-1}\right)$} \\
\cline { 1 - 5 } \cline { 5 - 8 } & & & $<5$ & $5-10$ & $10-20$ & $20-40$ & $>40$ \\
\hline Annual Average & 106 & & 54 & 21 & 19 & 10 & 2 \\
Annual Maximum & 163 & & 95 & 35 & 35 & 18 & 7 \\
Annual Minimum & 69 & & 27 & 9 & 8 & 3 & 0 \\
\hline
\end{tabular}

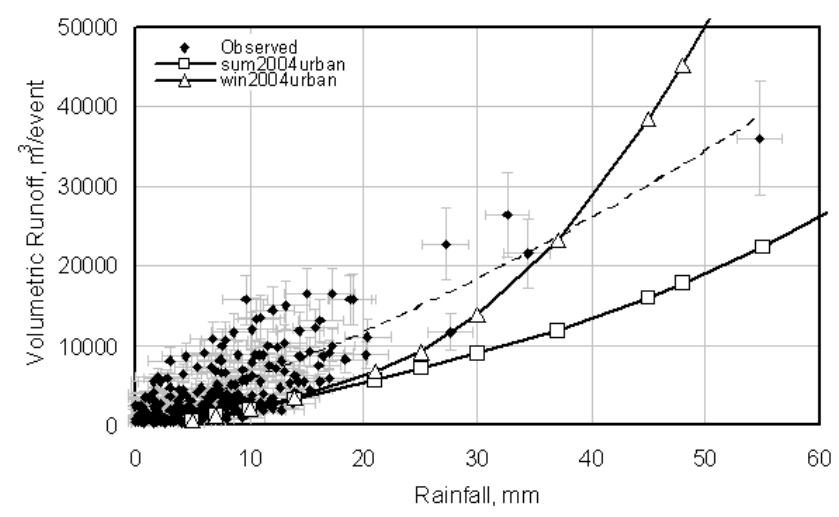

Fig. 7. Urban volumetric runoff (in legend: D - storage deficiency stage; $\mathrm{R}$ - storage recovery stage).

catchment, the volume of the river discharge was calculated for each of these events. The events were further separated into two groups based on the time of occurrence and the cumulative rainfall up to the date of the event to identify the storage recovery and storage deficiency conditions. As stated earlier, the cumulative rainfall threshold was set at $400 \mathrm{~mm}$.

In addition, the river discharge data was used to approximate runoff volume from the currently urbanised area in the north of the catchment, where the gauging station is located. The initial stage of each hydrograph shows the fast runoff from $6.6 \mathrm{~km}^{2}$ of the adjusted urban area. The time of concentration for urban discharge was found to be $2-3 \mathrm{~h}$, and a welldefined flow peak was recorded at this time for all available hydrographs. Such circumstances allow approximate estimation of volumetric runoff generated within the urban area, based on separation of this hydrograph component. The cumulative volume associated with urban stormwater discharge was then compared with the hourly rainfall data recorded at the nearest meteorological station.

\section{Modelling results}

Figures 6 and 7 show the relationship between the individual daily rainfalls and associated volumetric runoff for both observed and simulated data (Table 2). 
(a)

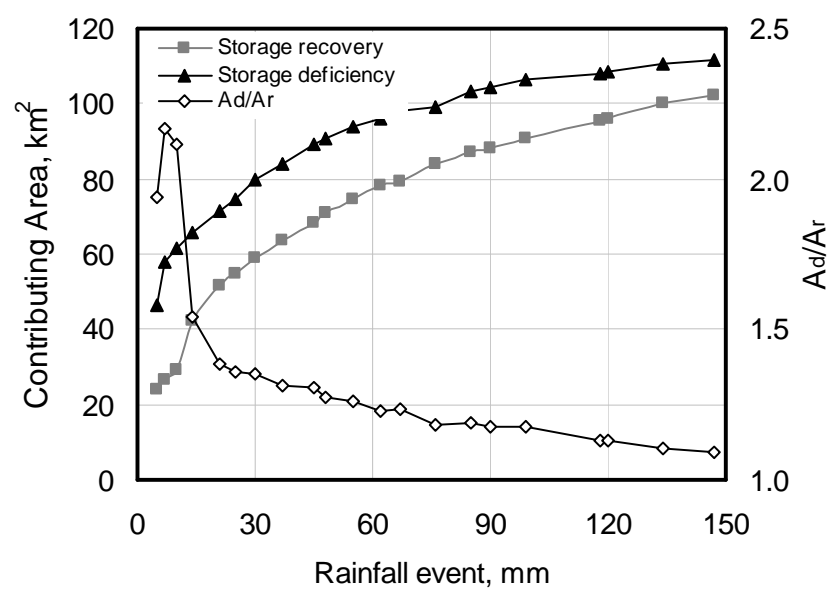

(b)

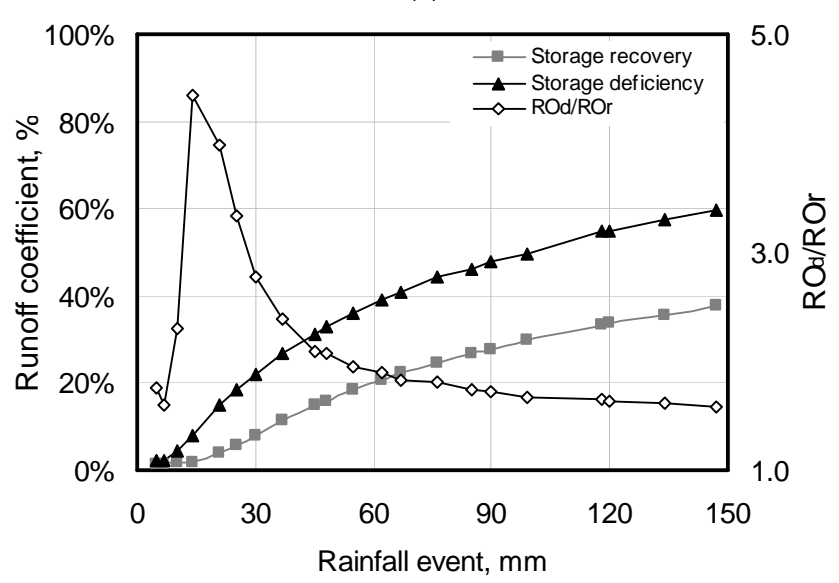

Fig. 8. Variation in (a) catchment contributing areas and (b) runoff coefficient, associated with these areas for various daily rainfall; here $\mathrm{RO}_{\mathrm{d}}$ and $\mathrm{RO}_{\mathrm{r}}$ are runoff coefficients under storage deficiency and storage recover stages, respectively, and $A_{\mathrm{d}}$ and $A_{\mathrm{r}}$ are contributing areas during those stages.

Table 2. Statistics of the model performance.

\begin{tabular}{lcc}
\hline Statistical measures & $\begin{array}{c}\text { Storage } \\
\text { Recovery } \\
\text { Stage }\end{array}$ & $\begin{array}{c}\text { Storage } \\
\text { Deficiency } \\
\text { Stage }\end{array}$ \\
\hline Scaled Mean Sum of Residuals & 0.04 & 0.06 \\
Scaled Root Mean Fraction Square & 0.63 & 0.13 \\
Scaled Root Mean Square & 0.05 & 0.08 \\
Coefficient of Determination & 0.89 & 0.82 \\
Correlation Coefficient & 0.98 & 0.96 \\
\hline
\end{tabular}

Both the observed data and the modelled results in Fig. 6 illustrate that the catchment runoff differs for events occurring during the storage recovery and the storage deficiency stages, when the catchment runoff generated by a similar rainfall event varies by more than a factor of two. Figure 8 also shows that such variations are related to a combination of two factors: (1) increase in the catchment runoff coefficient (1.5-4.4 times) and (2) increase in the catchment area contributing to the river flow (up to 2.2 times).

The catchment contributing area $\left(A_{\mathrm{cc}}\right)$ for selected rainfall events during the storage recovery stage and storage deficiency stage are shown in Fig. $9 . A_{\mathrm{cc}}$ is as low as $13 \%$ of the total catchment area for low rainfall events of $10 \mathrm{~mm}$, but not more than $75 \%$ of the total area even under extreme rainfall events of $137 \mathrm{~mm}$.

As shown in Fig. 7 the CCAA results reproduced the lowest range of the observed volumetric runoff from the urban area. This suggests that when applied for simulation of the future urban developments, the model results are likely to be conservative.

\subsection{Effect of variation in catchment contributing area on volumetric runoff}

The effect of variation in a catchment contributing area on the total discharge (or volumetric runoff) under a series of individual rainfall events was estimated for a number of cases, including various rainfall intensity, storage recovery and storage depletion stages and two soil types.

\subsubsection{Effect of catchment contribution area on the volumetric runoff for various daily rainfall events}

As shown in Fig. 7 the catchment area $(A)$ contributing to the total volumetric runoff $(Q)$ in the Southern River catchment increases for higher daily rainfall events. In order to estimate the effect of increasing contributing catchment area $\triangle A$ on total volumetric runoff, $\delta_{\mathrm{RF}}, A$ and $Q$ for various rainfall intensities were compared with $A_{5 \mathrm{~mm}}$ and $Q_{5 \mathrm{~mm}}$, which relates to the catchment response of the $5 \mathrm{~mm}$ rainfall event as a minimum considered in CCAA. For this case, Eq. (1) was adopted as follows:

$\delta_{\mathrm{RF}}=\frac{Q_{\Delta A i_{-} 5 \mathrm{~mm}}}{Q_{i}-Q_{5 \mathrm{~mm}}}(\%)$

where $Q_{\Delta A i_{-} 5 \mathrm{~mm}}$ is runoff from the area $\Delta A$, and $Q_{i}$ is runoff for rainfall intensity greater than $5 \mathrm{~mm}$.

The estimation was undertaken for the entire catchment and also for two sub-catchments characterised by different soil types; one occurs in the area of clay rich soil in the east $\left(15 \mathrm{~km}^{2}\right)$ and the other in the area of sandy soil in the west $\left(49 \mathrm{~km}^{2}\right)$ (Fig. 1).

Figure 10 shows the total runoff volume (Fig. 10a and b) and relative contribution of $A_{\mathrm{cc}}$ (Fig. 10c and d) for varying rainfalls. The effect of the change in catchment contributing area is most significant for more frequent rainfall events 


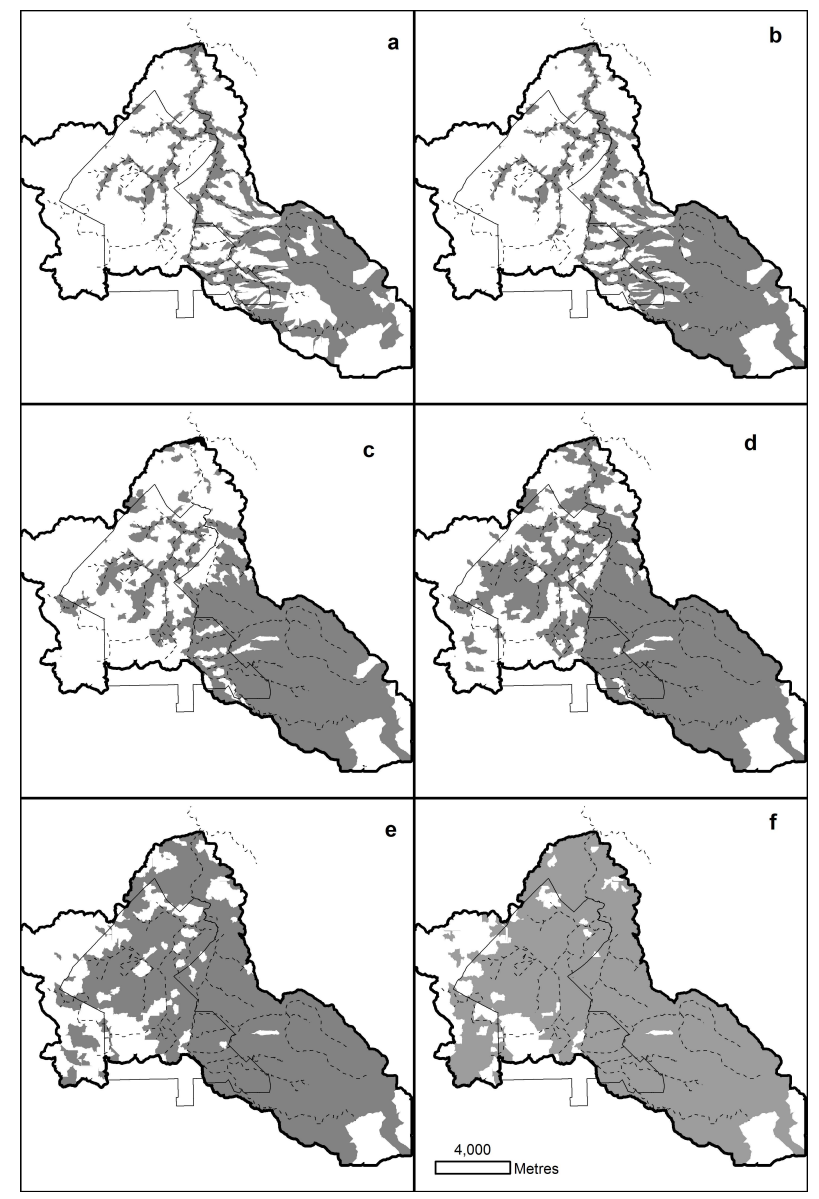

Fig. 9. Contributing catchments during the storage recovery stage under (a) $10 \mathrm{~mm}$, (c) $48 \mathrm{~mm}$, (e) $137 \mathrm{~mm}$ rainfall event; and during the storage deficiency stage under (b) $10 \mathrm{~mm}$, (d) $48 \mathrm{~mm}$, (f) $137 \mathrm{~mm}$ rainfall event.

$<14 \mathrm{~mm}$, which comprise $82 \%$ of annual daily rainfalls. For these events, up to a $60 \%$ increase in the catchment volumetric runoff is due to increase in $A_{\mathrm{cc}}$ (Fig. 10d, line 1). The $A_{\mathrm{cc}}$ effect is noticeably greater during the storage recovery stage (Fig. 10c, line 1) relative to its effect during storage deficiency stage (Fig. 10d, line 1).

In the sub-catchment with clay soil (Guilford Formation) the effect of increasing catchment contributing area dominates for rainfall events $<60 \mathrm{~mm}$ during the storage recovery stage (Fig. 10c, line 2). In this case, the increase in volumetric runoff attributed to $A_{\mathrm{cc}}$ variation is between $50 \%$ and $100 \%$. During the storage deficiency stage $A_{\mathrm{cc}}$ effect is limited to less than $20 \%$, with a greater effect related to the less intensive rainfall events $<14 \mathrm{~mm}$ (Fig. 10d, line 2).

In the sub-catchment with sandy soil (Bassendean Sand), the impact of the catchment contributing area dominates the increase in total volumetric runoff during storage recovery stage for rainfall greater than $20 \mathrm{~mm}$ (Fig. 10c, line 3). For these cases, the increase in the total volumetric runoff is more than $50 \%$ attributed to $A_{\mathrm{cc}}$. However it appears that the $A_{\mathrm{cc}}$ effect has no impact on the total volumetric runoff for lower daily rainfall. During the storage deficiency stage $A_{\mathrm{cc}}$ contribution within sandy sub-catchments is also significant and is greater than $40 \%$ for most rainfall events (Fig. 10d, line 3).

Catchment contributing area effect on total volumetric runoff appears to be greatest for the most frequent rainfall events, during early winter (storage recovery stage) and in the catchments with sandy soils.

\subsubsection{Effect of catchment contribution area on the volumetric runoff as result of catchment storage availability}

The model results indicated that the catchment area contributing to the total volumetric runoff for equal rainfall events is greater during the storage deficiency stage (Fig. 7). The effect of the increasing contributing area $\left(\delta_{\mathrm{St}}\right)$ between the two stages can be estimated as:

$\delta_{\mathrm{St}}=\frac{Q_{\Delta \mathrm{A}}}{Q_{\mathrm{D}}-Q_{\mathrm{R}}}(\%)$

where $Q_{\triangle \mathrm{A}}$ is the volumetric runoff generated at the storage deficiency stage within the area $\Delta A=A_{\mathrm{D}}-A_{\mathrm{R}}$; and $Q_{\mathrm{D}}$ and $Q_{\mathrm{R}}$ are catchment runoff during storage deficiency and storage recovery stages for the same intensity rainfall event.

At the catchment scale the effect of increasing $A_{\mathrm{cc}}$ is greatest during the most frequent rainfall events $(5$ and $7 \mathrm{~mm}$ ) (Fig. 11), but overall it is approximately $20 \%$.

The effect of the storage availability on volumetric runoff generation in sub-catchments is particularly profound where the sandy soil occurs. An increase of up to $92 \%$ is estimated for volumetric runoff due to catchment contributing area variation for the most frequent rainfall events $(<25 \mathrm{~mm}$ covering $93 \%$ of all daily rainfall events). In the sub-catchment with clay soils the CCA effect is also greater for more frequent events, but is generally lower than in the other considered cases for rainfall greater than $30 \mathrm{~mm}$.

\section{Effect of catchment urbanisation on the volumetric runoff}

The CCAA methodology was also applied for estimating the impact of urban development on the volumetric runoff. The area designated for urbanisation in the Southern River catchment is $64 \mathrm{~km}^{2}$ (Figs. 1 and $4 \mathrm{~b}$ ). The new development will include residential areas of various densities and some light industrial and commercial establishments.

As stated previously CCAA results generally reproduced the lowest range of the observed volumetric runoff and therefore the results are likely to be conservative with respect to potential changes in the volumetric runoff resulting from catchment urbanisation. The analysis was undertaken under the assumption that the development is fully completed. 
(a)

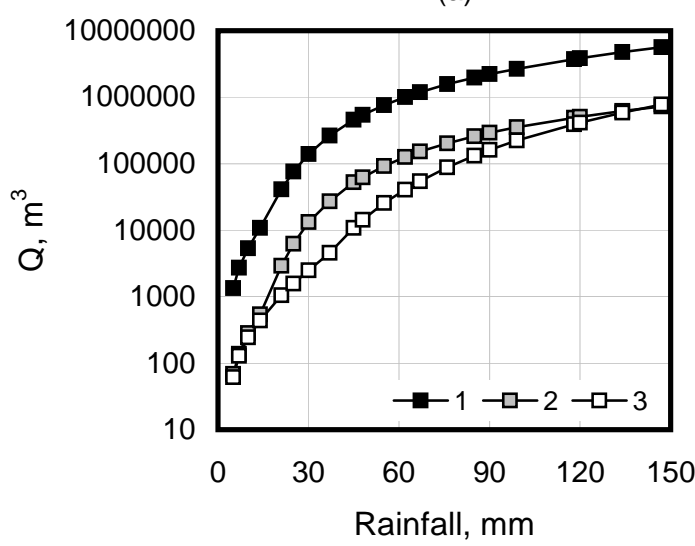

(c)

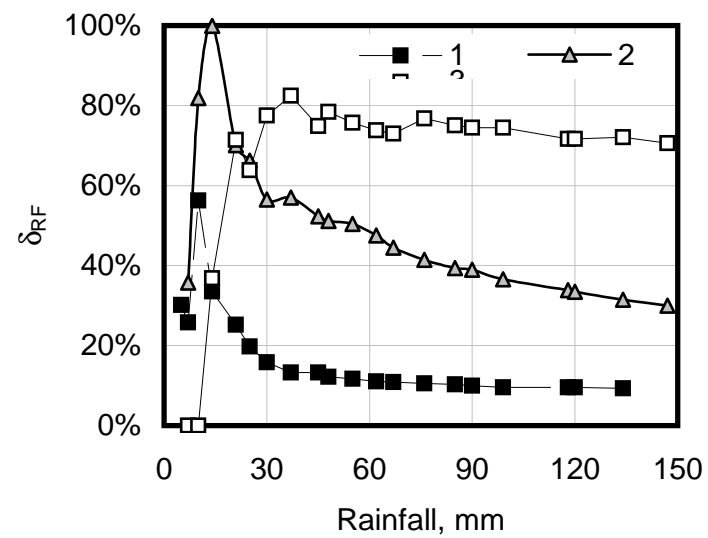

(b)

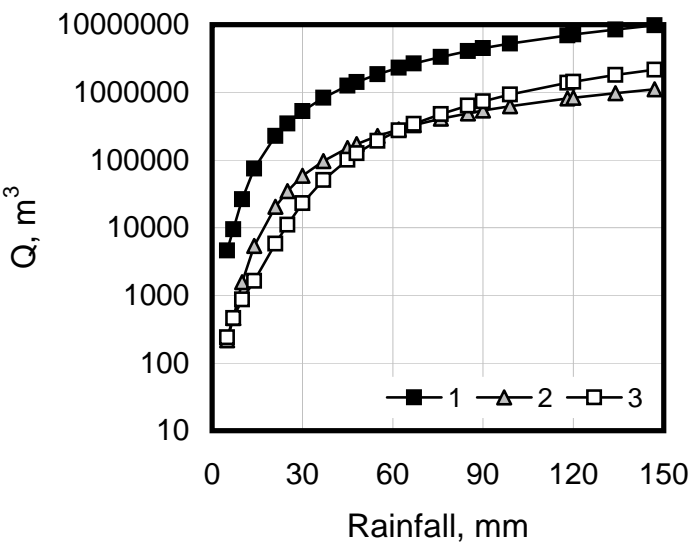

(d)

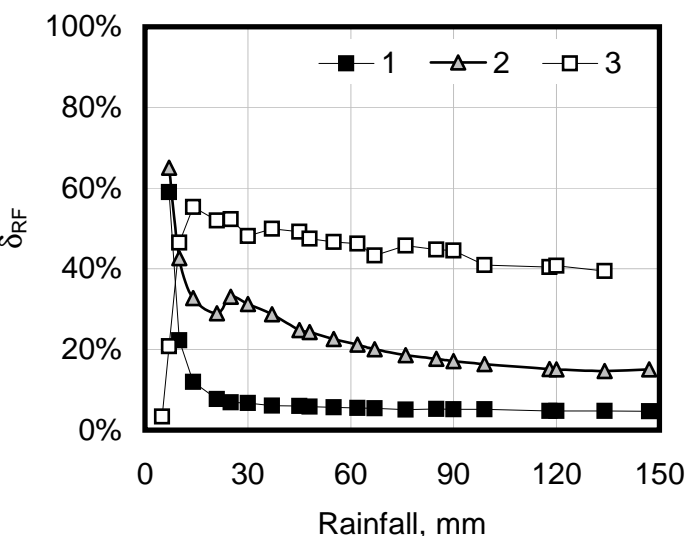

Fig. 10. Changes in catchment volumetric runoff $Q(\mathbf{a}, \mathbf{b})$ and the effect of the catchment contributing area $\delta(\mathbf{c}, \mathbf{d})$ on these changes during the storage recovery stage $(\mathbf{a}, \mathbf{c})$ and storage deficiency stage $(\mathbf{b}, \mathbf{d})$ for the entire catchment (1), sub-catchment with clay soil (2) and sub-catchment with sandy soil (3).

(a)

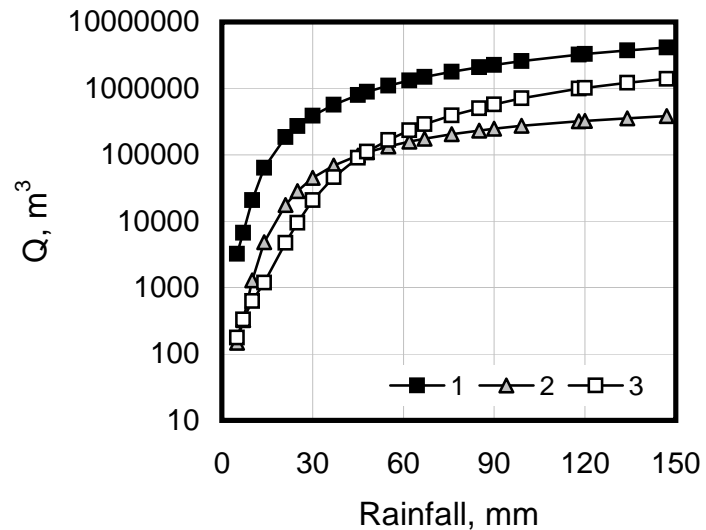

(b)

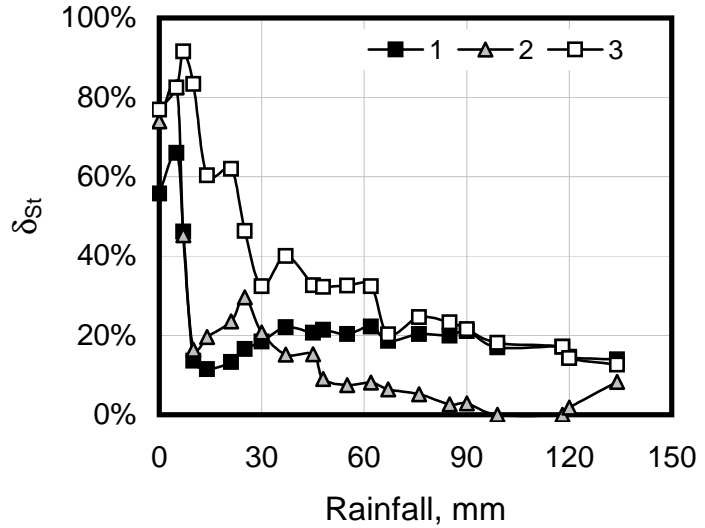

Fig. 11. Changes in catchment runoff $Q$ between two hydrological stages (storage recovery and storage deficiency) (a) and the effect of the catchment contributing area $\delta(\mathbf{b})$ on these changes for the entire catchment (1), sub-catchment with clay soil (2) and sub-catchment with sandy soil (3). 
(a)

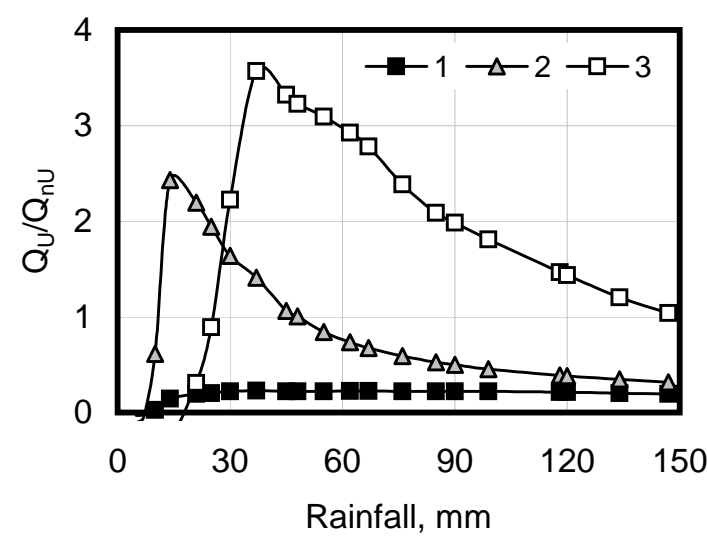

(c)

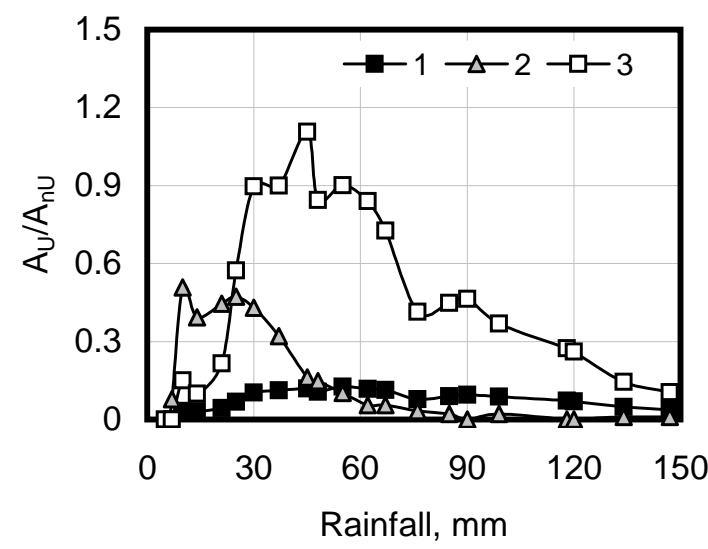

(e)

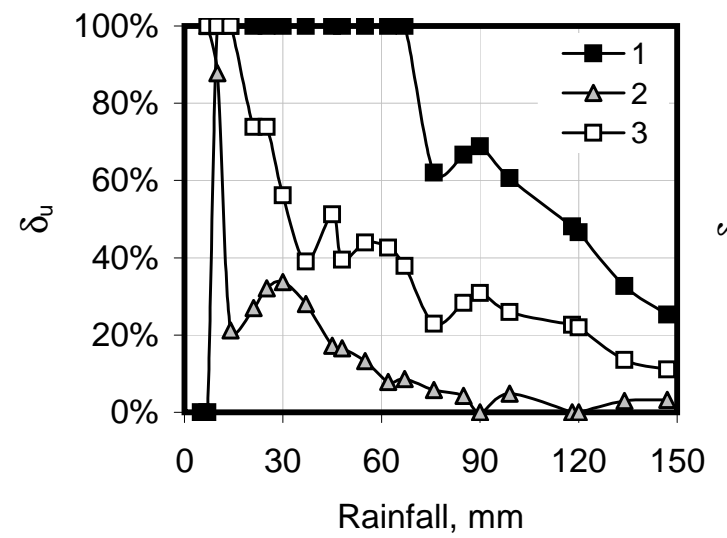

(b)

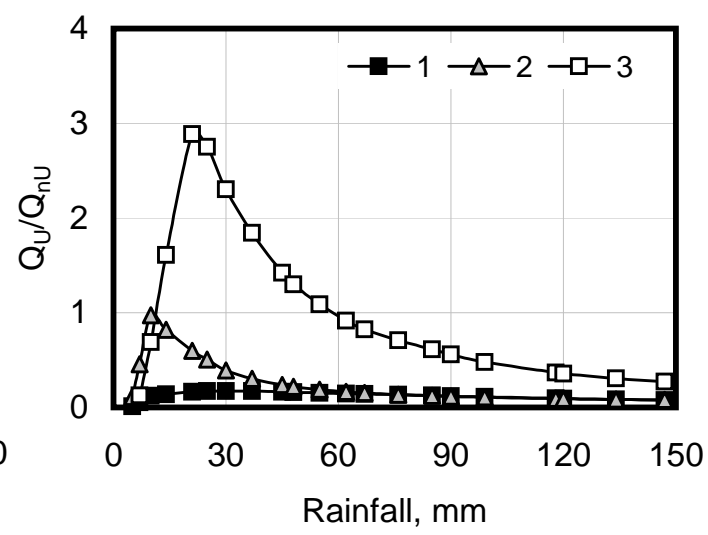

(d)

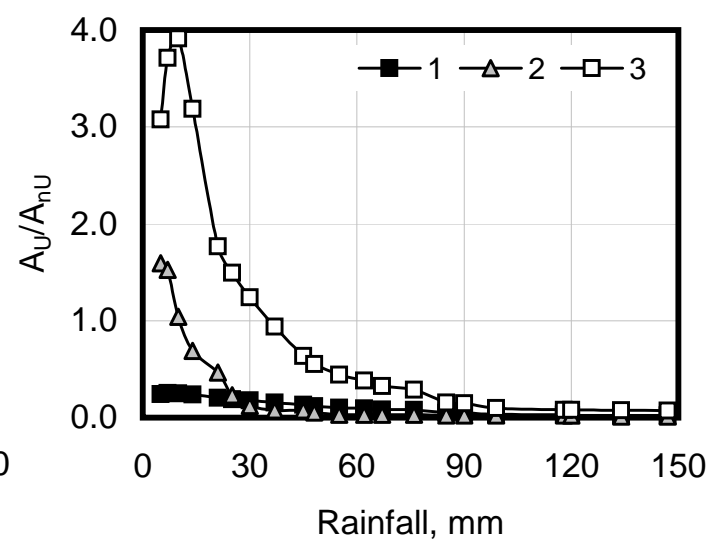

(f)

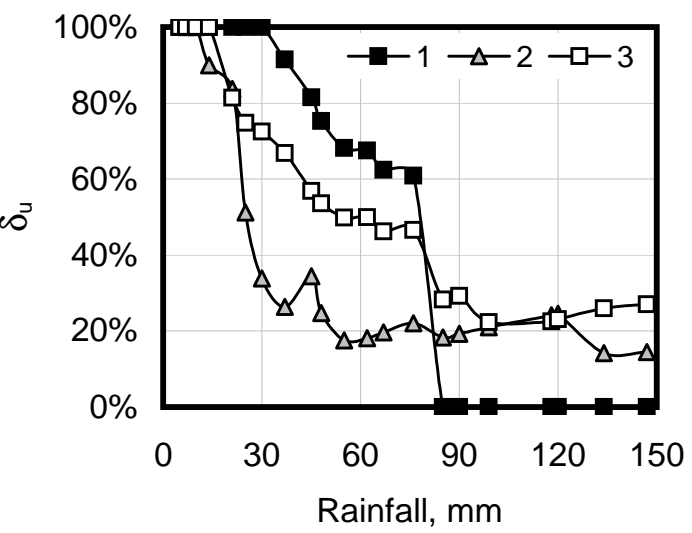

Fig. 12. Effect of urbanisation on the catchment runoff $Q(\mathbf{a}, \mathbf{b})$, the catchment contributing area Acc (c, d) and the effect of the increase in catchment contributing area on volumetric runoff $\delta(\mathbf{e}, \mathbf{f})$ during the storage recovery stage $(\mathbf{a}, \mathbf{c}, \mathbf{e})$ and storage deficiency stage $(\mathbf{b}, \mathbf{d}, \mathbf{f})$ for the entire runoff (1), sub-catchment with clay soil (2) and sub-catchment with sandy soil (3).

The analysis determined that urbanisation increases the total volumetric runoff in the entire catchment and in the individual sub-catchments (Fig. 12a and b). The cumulative impact of urbanisation on the catchment volumetric runoff under individual rainfall events was estimated to be up to $25 \%$. The variations were greater for the storage recovery stage and particularly evident in the sandy sub-catchments, where the volumetric runoff was estimated to be up to 3.5 -fold greater in comparison with pre-development conditions (Fig. 12a). However the impact of urbanisation was only evident here for the rainfall events greater than $10 \mathrm{~mm}$. 
Similarly to the previous analysis, the effect of the increasing catchment contributing area $\left(\delta_{U}\right)$ on the increase in total volumetric runoff between predevelopment $(n U)$ and postdevelopment $(U)$ conditions was estimated as:

$\delta_{U}=\frac{Q_{\Delta \mathrm{A}}}{Q_{U}-Q_{n U}}(\%)$

where $Q_{\Delta \mathrm{A}}$ is the volumetric runoff which is likely to be generated after urbanisation within the area $\Delta \mathrm{A}=A_{U}-A_{n U}$ for a given rainfall event; and $Q_{U}$ and $Q_{n U}$ are the catchment runoff for predevelopment $(n U)$ and post-development $(U)$ conditions for the same intensity rainfall event.

Figure $12 \mathrm{c}$ shows that the contributing area increased for the most frequent rainfall events in the entire catchment, and in the individual sub-catchments. Once again the effect of the catchment contributing area increase was particularly evident in sandy sub-catchment during the storage deficiency stage, where $A_{\text {cc }}$ increased 4-fold compared with pre-development conditions (Fig. 12d).

The effect of the catchment contributing area was significant during both hydrological stages for the entire catchment and for the sub-catchments (Fig. 12e and f). The results of the analysis confirm the previously reported evidence that urbanisation may increase the total volumetric runoff for individual storm events (Wang et al., 2005). However in a flat sandy catchment the increase in total volumetric runoff as a result of urbanisation is also related to the increase in the catchment contributing area, which may cause up to $100 \%$ stormwater yield increase.

\section{Discussion and conclusions}

The method for CCAA provides an insightful, yet simple tool for the evaluation of catchment response to individual rainfall events. The method allowed simulating the hydrological connectivity of flat catchments and volumetric runoff related to individual daily rainfall events by defining the catchment area contributing to catchment runoff. In some ways the approach is similar to one discussed by Cammeraat (2002) for arid and temperate climates. But in addition to his observation on rainfall intensity and rainfall amount required to trigger the runoff generation, the results of this study indicate that the changes in catchment contributing area may influence this relationship.

As in other studies (Aryal et al., 2003; Beven, 1997) the results reported here suggest that runoff can be generated in a large area of the catchment, but its contribution to outflow from the catchment may be limited from various part of the catchment. However in addition to "effective slope length" (Aryal et al., 2003) or "dynamic contributing areas" (Beven, 1997), this can also be associated with a compensating effect of surface depressions in flat landscapes, when only "excess of runoff" generated within a depression under a single rainfall event can be passed down gradient. This also could be considered as extreme case or macro-scale of surface roughness. However this term is mostly used to define micro-scale hydrological processes (Slattery and Bryan, 1992). They showed the effect of differential swelling, surface sealing or crusting and their dynamic changes during a storm can influence hydraulic roughness.

The developed CCAA GIS-based model was applied to the Southern River Catchment, Western Australia, and the results were in a good agreement with the observed volumetric catchment runoff measured in the outflow from the catchment. The model was also applied to define the rainfallrunoff characterisation in an individual sub-catchment with specific land use and land cover characteristics (e.g. land use, geology, during storage recovery or storage deficiency stages of the catchment hydrological cycle).

The analyses suggest that the effect of variation in catchment contributing area on volumetric runoff under individual rainfall events can be significant, particularly for the most frequent rainfall events $(<40 \mathrm{~mm})$. For those events, up to $50 \%$ increase in the total volumetric runoff during higher intensity rainfall events can be associated with greater hydrological connectivity within the catchment. Similarly it was shown that $A_{\mathrm{cc}}$ for the same rainfall event is greater when rainfall infiltration is limited, e.g. during the storage deficiency stage of the annual hydrological cycle which is associated with the maximum level of soil saturation. The latter is consistent with James and Roulet (2007), who showed more than 5 fold increases in runoff coefficient when soil moisture content reach a certain threshold.

The model also provided insightful results on changes in rainfall/runoff relationship under land use change when applied for the simulation of new urban development in the Southern River catchment. Such changes in catchment hydrological connectivity were defined by Bracken and Croke (2007) as "dynamic". In a catchment with a shallow groundwater table the requirement to control water levels commonly results in the introduction of drainage networks in new urban developments in Perth. It was shown that an increase in runoff from the newly urbanised area is not only related to variation in rainfall/runoff response under new land cover conditions, but also to a greater catchment area contributing to the river flow. Similar observations were reported for agricultural areas where artificial drainage network was shown to increases catchment connectivity (Frey et al., 2009; Payraudeau et al., 2009), but the effect of urbanisation on catchment connectivity is not widely reported.

This effect was greatest for the most frequent rainfall events similarly to those reported by Niehoff et al. (2002) and Camorani et al. (2005), but also during autumn and early winter, the storage recovery stage of the annual hydrological cycle. The impact of urbanisation is particularly evident in sandy catchments, which are largely disconnected in predevelopment conditions. These outcomes suggested that for new urban development the application of Water Sensitive Urban Design (WSUD) principles (van Roon, 2007), aiming 
to reduce the runoff from the urbanised areas, are particularly important in such environment as they allow controlling the catchment connectivity and also contribute to minimising water quality deterioration in any receiving water body. The links between water quality and hydrological connectivity is yet another important application for the hydrological connectivity concept, which has been applied mainly for agricultural land use (Payraudeau et al., 2009).

The analysis showed that catchment surface depressions are important relief elements which influence the catchment response to rainfall events and the rainfall/runoff relationship. The inclusion of these features in the hydrological analysis becomes particularly important when land use changes are considered. However, hydrological models typically deploy larger computational cells, which in this case would miss some of the features found to be important for estimation of the rainfall/runoff dynamics of this catchment. In some cases the surface depressions are recommended to be excluded when the "effective" contributing area is estimated (Olivera and Maidment, 1999).

The limitation of the approach in its current form is that it does not allow for estimation of flow rates, including subdaily peak flow. It is also not suitable for analysing a sequence of storm events, which may have a similar effect to a large single event. To address this, the addition of channel flow routing to the method is required. Since the modelling is based on independent daily rainfall events, peak flow would be still outside of the scope of the expanded method.

\section{Appendix A}

Glossary

Catchment Contributing
Area Analysis
(CCAA)

The GIS-based methodology developed to define (a) catchment area contributing to river flow during an individual rainfall event, and (b) total volumetric runoff generated during the event

\begin{tabular}{ll}
\hline Catchment Contributing & $\begin{array}{l}\text { Catchment area contribut- } \\
\text { ing to river flow during an } \\
\text { individual rainfall event }\end{array}$ \\
\hline Catchment Volumetric & $\begin{array}{l}\text { Total storm yield generated } \\
\text { in a catchment during an in- } \\
\text { dividual rainfall event }\end{array}$ \\
\hline Dunoff $(Q)$ & Total daily rainfall \\
\hline
\end{tabular}

Hydrol. Earth Syst. Sci., 15, 547-559, 2011

\begin{tabular}{ll}
\hline Effect of Catchment Con- & Proportion of a total \\
tributing Area on variation & volumetric runoff associ- \\
in Catchment Volumetric & ated with variation in the \\
Runoff $(\delta)$ & Catchment Contributing \\
& Area and Catchment \\
& Volumetric Runoff
\end{tabular}

Number of rainfall events Number of daily records a year (NRF) per year

Runoff Coefficient (RO) A measure of catchment area response to a given rainfall intensity, dependant on the catchment land cover, land use, soil moisture and topography.

Storage deficiency stage The period in the Southern River hydrological cycle when the storage in shallow groundwater and wetlands is filled to full capacity (normally occurs when the annual rainfall is greater than $400 \mathrm{~mm}$ )

Storage recovery stage

The period in the Southern River hydrological cycle when the storage in shallow groundwater and wetlands is recovering (normally occurs in the beginning of a wet season limited by the time when annual rainfall reaches $400 \mathrm{~mm}$ )

Total storage capacity of a Volume of an individual relief depression $(\mathrm{Vi})$ relief depression which is limited by the lowest elevation point that allows overflow to the surrounding surfaces

USDA Curve Number A parameter that controls
(CN) a non-linear equation to convert storm rainfall to storm runoff, based on soil type, plant cover, impervious surfaces and hydrologic condition

Variation in the Catch- Increase in catchment area ment Contributing Area contributing to river flow between two scenarios between two scenarios $(\Delta A)$

\begin{tabular}{ll}
\hline Variation in Volumetric & Increase in volumetric \\
Runoff between two & runoff between two \\
scenarios $(\Delta Q)$ & scenarios
\end{tabular}

www.hydrol-earth-syst-sci.net/15/547/2011/ 
Acknowledgements. The work reported was undertaken by CSIRO Land and Water with funding from the CSIRO National Flagship Water for a Healthy Country and the Western Australian Premiers Water Foundation. It is also linked to multi-agency activities in the Southern River Catchment which are coordinated by an MOU group. The major stakeholders are WA Water Corporation, WA Department of Water, Swan River Trust, local governments of the City of Armadale and City of Gosnells, and the Armadale Redevelopment Authority.

Edited by: H. Cloke

\section{References}

Ambroise, B.: Variable "active" versus "contributing" areas or periods: a necessary distinction, Hydrol. Process., 18, 1149-1155, doi:10.1002/hyp.5536, 2004.

Aryal, S. K., Mein, R. G., and O'Loughlin, E. M.: The concept of effective length in hillslopes: assessing the influence of climate and topography on the contributing areas of catchments, Hydrol. Process., 17, 131-151, doi:10.1002/hyp.1137, 2003.

Beven, K. J.: Experiments with a finite element model of hillslope hydrology - the effect of topography, Surface and Subsurface Hydrology, 37-51, 1979.

Beven, K. J.: Topmodel: A critique, Distributed hydrological modelling: applications of the TOPMODEL concept, 1-17, 1997.

Bracken, L. J. and Croke, J.: The concept of hydrological connectivity and its contribution to understanding runoffdominated geomorphic systems, Hydrol. Process., 21, 17491763, doi:10.1002/hyp.6313, 2007.

Bryan, R. B. and Yair, A.: Perspectives on studies of badland geomorphology, in: Badland Geomorphology and Piping, edited by: Bryan, R. B. and Yair, A., GeoBooks; Norwich, 1-12, 1982.

Bull, L. J., Kirkby, M. J., Shannon, J., and Dunsford, H. D.: Predicting hydrologically similar surfaces (HYSS) in semi-arid environment, Adv. Environ. Monitor. Modell., 2, 1-13, 2003.

Burns, D., Vitvar, T., McDonnell, T., Hassett, J., Duncan, J., and Kendall, D.: Effects of suburban development on runoff generation in the Croton River basin, New York, USA, J. Hydrol., 311, 266-281, 2005.

Callow, J. N. and Smettem, K. R. J.: The effect of farm dams and constructed banks on hydrologic connectivity and runoff estimation in agricultural landscapes, Environ. Modell. Softw., 24, 959968, doi:10.1016/j.envsoft.2009.02.003, 2009.

Cammeraat, L. H.: A review of two strongly contrasting geomorphological systems within the context of scale, Earth Surf. Proc. Land., 27, 1201-1222, doi:10.1002/esp.421, 2002.

Camorani, G., Castellarin, A., and Brath, A: Effects of land-use changes on the hydrologic response of reclamation systems, Phys. Chem. Earth, 30, 561-574, 2005

ESRI: Environmental Systems Research Institute, Inc., http://www. esri.com/, last accessed: 3 February, 2009a.

ESRI ArcGIS: A Complete Integrated System, http://www.esri. com/software/arcgis/, last accessed: 3 February, $2009 \mathrm{~b}$.

Frey, M. P., Schneider, M. K., Dietzel, A., Reichert, P., and Stamm, C.: Predicting critical source areas for diffuse herbicide losses to surface waters: Role of connectivity and boundary conditions, J. Hydrol., 365, 23-36, doi:10.1016/j.jhydrol.2008.11.015, 2009.
Grove, M. H. J., Engel, B., and Muthukrishnan, S.: Impacts of urbanization on surface hydrology, Little Eagle Creek, Indiana, and analysis of LTHIA model sensitivity to data resolution, Phys. Geogr., 22, 135-153, 2001.

Hu, W. W., Wang, G. X., Deng, W., and Li, S. N.: The influence of dams on ecohydrological conditions in the Huaihe River basin, China, Ecol. Eng., 33, 233-241, doi:10.1016/j.ecoleng.2008.04.003, 2008.

James, A. L. and Roulet, N. T.: Investigating hydrologic connectivity and its association with threshold change in runoff response in a temperate forested watershed, Hydrol. Process., 21, 33913408, doi:10.1002/hyp.6554, 2007.

Jennings, D. B. and Jarnagian, S. T.: Changes in anthropogenic impevious surfaces, precipitation and daily streamflow discharge: a historical perspective in a mid-atlantic subwatershed, Landscape Ecol., 17, 135-153, 2001.

Kirkby, M., Bracken, L., and Reaney, S.: The influence of land use, soils and topography on the delivery of hillslope runoff to channels in SE Spain, Earth Sur. Proc. Land., 27, 1459-1473, doi:10.1002/esp.441, 2002.

Maidment, D. R.: Arc Hydro: GIS for water resources, ESRI Press, Redlands, California, USA, p. 220, 2002,

Niehoff, D., Fritsch, U., and Bronstert, A: Land-use impacts on storm-runoff generation: scenarios of land-use change and simulation of hydrological response in a meso-scale catchment in SW-Germany, J. Hydrol., 267, 80-93, 2002.

Olivera, F. and Maidment, D.: Geographic information systems (GIS)-based spatially distributed model for runoff routing, Water Resour. Res., 35, 1155-1164, 1999.

Payraudeau, S., Junker, P., Imfeld, G., and Gregoire, C.: Characterizing hydrological connectivity to identify critical source areas for pesticides losses, 18th World IMACS/MODSIM Congress, Cairns, Australia, 13-17 July 2009, 1879-1885, 2009.

Python Software Foundation: Python Programming Language - Official Website, http://www.python.org/, last accessed: 3 February, 2009.

Rose, S. and Peters, N.: Effects of urbanization on streamflow in the Atlanta area (Georgia, USA): a comparative hydrological approach, Hydrol. Process., 15, 1441-1457, 2001.

Slattery, M. C. and Bryan, R. B.: Hydraulic conditions for rill incision under simulated rainfall - a laboratory experiment, Earth Surf. Proc. Land., 17, 127-146, 1992.

USDA - Urban Hydrology for Small Watersheds: Technical Release 55, United States Department of Agriculture, Conservation Engineering Division, p. 164, 1986.

van Roon, M.: Water localisation and reclamation: Steps towards low impact urban design and development, J. Environ. Manage., 83, 437-447, 2007.

Wang, Y., Choi, W., and Deal, B. M. : Long-term impacts of landuse change on non-point source pollutant loads for the St. Louis metropolitan area, USA, Environ. Manage., 35, 194-205, 2005.

Western, A. W., Bloschl, G., and Grayson, R. B.: Toward capturing hydrologically significant connectivity in spatial patterns, Water Resour. Res., 37, 83-97, 2001. 